\title{
Use of Microarray Technology to Improve DNA Vaccines in Fish Aquaculture - The Rhabdoviral Model
}

\author{
P. Encinas ${ }^{1}$, E. Gomez-Casado ${ }^{1}$, A. Estepa ${ }^{2}$ and J.M. Coll ${ }^{1}$ \\ ${ }^{1}$ Instituto Nacional Investigaciones Agrarias, \\ Departamento Biotecnología, INIA, Madrid \\ ${ }^{2}$ Universidad Miguel Hernández, IBMC Elche \\ Spain
}

\section{Introduction}

Fish rhabdoviral infections, specially those caused by novirhabdoviruses, can be tackled with commertial DNA vaccines such as the one against infectious haematopoietic necrosis virus (IHNV) (Salonius et al., 2007). Nevertheless, rhabdoviral diseases continue to pose a considerable threat to aquaculture because a number of practical problems regarding vaccination remain unsolved (for instance, mass delivery methods for small fish and requirements for safer vectors). Furthermore, some fish rhabdoviroses appear to be spreading to wild-type species.

Theoretically, efficient DNA vaccines could be used for any fish pathogen, such as other viruses (nodaviruses and orthomyxoviruses, for instance), bacteria and parasites. However, in practice, many fish DNA vaccines do not perform satisfactorily in most other pathogens than novirhabdoviruses. Therefore, fish novirhabdoviral vaccines are suitable models in which to study why similar DNA vaccines have not been successfully developed for other viruses (Gomez-Casado et al., 2011; Kurath, 2008). Those studies include the use of microarrays.

To date, effective vaccines against fish rhabdoviruses have been achieved simply by using their glycoprotein G gene (Einer-Jensen et al., 2009; Kurath, 2008; Kurath et al., 2007; Lorenzen, 2000; Lorenzen et al., 2009; Lorenzen \& LaPatra, 2005). The glycoprotein G of rhabdoviruses is a widely studied antigen in fish (Bearzotti et al., 1995; LaPatra et al., 1994; McAllister et al., 1974; Vestergaard-Jorgensen, 1972; Winton et al., 1988) and its crystal structure has recently been elucidated in a similar mammalian rhabdovirus (Roche et al., 2006; Roche et al., 2007).

Most of our present knowledge about the factors that affect DNA vaccination efficacy in fish (vaccine dosage, delivery route, water quality, host species/size, time to challenge, severity of challenge, viral strain, etc) derives from work on fish rhabdoviral models (Kurath, 2008). Thus, the first fish DNA vaccines against IHNV were reported in 1996 (Anderson et al., 1996a; Anderson et al., 1996b) and against viral haemorrhagic septicemia virus (VHSV) in 1998 (Lorenzen et al., 1998). In 2005, Vical-Aqua Health Ltd. of Canada (Novartis APEX- 
IHN) received authorization to commertialize an IHNV DNA vaccine (Salonius et al., 2007). In support of their licensing, millions of salmon were vaccinated in British Columbia in 2004 and 2005. However, there are no reports on the efficacy of this vaccine against natural viral challenges (Kurath, 2008; Salonius et al., 2007).

When injected intramuscularly in each fish, plasmid-based G glycoprotein-coding rhabdoviral vaccines induce long-term (months) specific immunity, preceded by an early (4-8 days) non-specific protective response (Kim et al., 2000; Lorenzen, 2000; Lorenzen et al., 2002). Non-specific short-term protective immunity results from the induction of interferon- $m x$ and related genes, while specific long-term protection may have this effect as a result of the induction of $\mathrm{G}$ glycoprotein gene-specific antibody or cellular responses (Kurath et al., 2007). However, most changes in gene expression that occur with resistance mechanisms in short-term and long-term immunity are not fully understood (Goetz \& MacKenzie, 2008). Furthermore, more basic knowledge on mucosal immunity is required to move rhabdoviral DNA vaccines from the laboratory into the field, as existing vaccines still require either intramuscular injection in individual fish or stronger (adjuvanted) immune responses to facilitate mass delivery methods, such as those using oral(delasHeras et al., 2010; Tian et al., 2008) or ultrasound-aided (Fernandez-Alonso et al., 2001) immunization. Studies using microarrays could greatly contribute to furthering this basic knowledge (Secombes, 2008).

Theoretically, for best performance an optimal vaccination should mimic viral infection steps such as entry and replication. For instance, since the entry of rhabdoviruses would be first detected by cellular membrane toll-like receptors (TLRs) through the G glycoprotein and their later cytoplasmic replication by endosomal TLRs through dsRNA intermediates, the question arises as to whether DNA vaccines should include not only the G glycoprotein gene but also dsRNA intermediates (ie.: RNA hairpins). Again, new data obtained from microarrays could shed some light on these possibilities.

As established by quantitative RT-qPCR before the advent of microarrays, 4 to 8 days after DNA vaccination by intramuscular injection, gene expression by fish haematopoietic organs showed an increase in interferon-inducible $m x$ (Acosta et al., 2005; Boudinot et al., 1998; McLauchlan et al., 2003; Purcell et al., 2004; Robertsen, 2008; Tafalla et al., 2007), virallyinduced genes (Vig) (Boudinot et al., 1999; Boudinot et al., 2001) and $m h c$ and tor genes (Takano et al., 2004).

In this context, the recent availability of fish microarrays (Martin et al., 2008), which allow the expression profiling of thousands of genes simultaneously, has provided new opportunities to further study fish immunological responses in several rhabdovirus/fish models.

Expressed sequence tag (EST)-based microarrays of the Japanese flounder, trout, salmon and zebrafish have been used in gene-discovery efforts. These studies included infections with IHNV (MacKenzie et al., 2008; Purcell et al., 2006a), VHSV(Byon et al., 2005; Byon et al., 2006; Encinas et al., 2010) and hirame rhabdovirus (HRV)(Yasuike et al., 2007) (Table 1). However, no studies have reported on the largest microarrays that have recently become available, such as the $\sim 32 \mathrm{~K} \mathrm{cDNA}$ of salmonids (von Schalburg et al., 2008) and the $\sim 37 \mathrm{~K}$ 60-mer oligos of trout (Salem et al., 2008), most probably due to the complexity of the interpretation of the data. 


\begin{tabular}{|c|c|c|c|c|c|}
\hline Fish name & $\begin{array}{l}\text { Genus } \\
\text { species }\end{array}$ & $\begin{array}{l}\text { Size } \\
, \sim K\end{array}$ & Type & Name & References \\
\hline \multicolumn{6}{|l|}{ Flatfish } \\
\hline $\begin{array}{l}\text { Japanese } \\
\text { flounder }\end{array}$ & $\begin{array}{l}\text { Paralichthys } \\
\text { olivaceus }\end{array}$ & 1 & cDNA & $\begin{array}{l}\text { HRV-infected } \\
\text { Leukocytes }\end{array}$ & $\begin{array}{l}\text { (Aoki et al., 1999) } \\
\text { (Nam et al., 2000) }\end{array}$ \\
\hline $\begin{array}{l}\text { European } \\
\text { flounder }\end{array}$ & $\begin{array}{l}\text { Platichthys } \\
\text { flesus }\end{array}$ & 3 & cDNA & GENIPOL & (Diab et al., 2008) \\
\hline $\begin{array}{l}\text { Atlantic } \\
\text { halibut }\end{array}$ & $\begin{array}{l}\text { Hipppoglossus } \\
\text { hyppoglossus }\end{array}$ & 7 & oligo & --- & (Douglas et al., 2008) \\
\hline Turbot & $\begin{array}{l}\text { Scophthalmus } \\
\text { maximus }\end{array}$ & 3 & oligo & $\begin{array}{l}\text { Aeromonas- } \\
\text { infected organs }\end{array}$ & (Pardo et al., 2009) \\
\hline
\end{tabular}

Salmonids

\begin{tabular}{|c|c|c|c|c|c|}
\hline $\begin{array}{l}\text { Atlantic } \\
\text { salmon }\end{array}$ & $\begin{array}{l}\text { Salmo } \\
\text { salar }\end{array}$ & 16 & cDNA & TRAITS-SGP & (Salem et al., 2008) \\
\hline $\begin{array}{l}\text { Atlantic } \\
\text { salmon }\end{array}$ & salmonids & 32 & cDNA & GRASP & $\begin{array}{c}\text { (von Schalburg et al., } \\
\text { 2008) } \\
\text { (Koop et al., 2008) }\end{array}$ \\
\hline $\begin{array}{l}\text { Rainbow } \\
\text { trout }\end{array}$ & $\begin{array}{c}\text { Oncorhynchus } \\
\text { mykiss }\end{array}$ & 37 & $\begin{array}{l}\text { oligo } \\
60 \mathrm{mer}\end{array}$ & RTGI & (Salem et al., 2008) \\
\hline \multicolumn{6}{|c|}{ Other species } \\
\hline Zebrafish & $\begin{array}{l}\text { Danio } \\
\text { rerio }\end{array}$ & 40 & $\begin{array}{l}\text { oligo } \\
60 \mathrm{mer}\end{array}$ & ---- & Agilent (commertial) \\
\hline
\end{tabular}

GENIPOL, http://www.pleuronectes.ca. GRASP, http://web.uvic.ca/grasp/microarray/array.html. TIGR, http://biocomp.dfci.harward.edu/tgi/cgi-bin/tgi/gimain.pl?gudb=salmon. TRAITS-SGP, http://www.traitsdb.stir.ac.uk. RTGI, http://compbio.dfci.harvard.edu/tgi/cgibin/tgi/gimain.pl?gudb=r_trout. Zebrafish, http://www.ensembl.org/Danio_rerio/Info/Index and Sanger zebrafish project http://www.sanger.ac.uk/Projects/D_rerio/.

Table 1. Summary of rhabdoviral-sensitive fish species with microarrays in different stages of development.

In this review we focus on the data published on the use of microarrays for the identification of rhabdoviral-induced genes with properties that make them candidate adjuvants for the improvement of fish DNA vaccines.

\section{Vertebrate viral infections, vaccination and adjuvants}

Pathogen-associated molecular patterns (PAMPs) are sensed in higher vertebrates by pattern recognition receptors (PRRs). There are several PRR classes (retinoic acid-inducible gene-like helicases, nucleotide-binding oligomerization domain-like receptor, peptide recognition proteins, etc). The most studied PRRs belong to the family of toll like receptors (TLRs) (Manicassamy \& Pulendran, 2009). When expressed at the cell (TLRs numbers $1,2,4,5,6,10,11)$ and at the endosomal $(3,7,8,9)$ membranes, TLRs detect PAMPs outside and inside the cells, respectively. Most natural infections start through mucosal surfaces that contain dendritic cells (DCs) specialized in sensing PAMPs through their cell-specific TLRs- 
enriched membranes (Iwasaki, 2007a; Iwasaki, 2007b; Thompson \& Iwasaki, 2008). After recognition of their corresponding PAMP, TLRs generates TLR-mediated signals, these resulting in a complex signalling network whose integration by the host determines the final immune response (Manicassamy \& Pulendran, 2009).

Since the most effective vaccinations are obtained after infections with live or attenuated pathogens, several PAMPs from a unique pathogen (such as external glycoproteins and internally synthesized dsRNA/glycoproteins in rhabdoviruses) simultaneously stimulate several TLRs. In contrast, dead recombinant protein subunits and antigenic genes contain fewer PAMPs than live/attenuated pathogens. Nevertheless, single PAMPs have also been used to immunize against live pathogens, mostly with the help of adjuvants to replace the missing PAMPs. Therefore, the purpose of vaccine adjuvants is to increase the immune responses of otherwise weak individual PAMPs.

Most adjuvants in mammals are believed to target professional antigen-presenting cells, such as tissue DCs (De Gregorio et al., 2009; Lambrecht et al., 2009). The expression patterns of pro-inflammatory genes such as cytokines, chemokines, MHC and co-estimulatory molecules are altered in adjuvant-targeted DCs (Figure 1). Subsequently, maturing DCs migrate to lymph nodes and activate naive CD4+ (helper) and CD8+ (cytotoxic) T cells to produce antigen-specific antibodies, cytotoxic cells, antimicrobial peptides and regulatory cytokines (Craig et al., 2009; Longhi et al., 2009; Manicassamy \& Pulendran, 2009; Secombes, 2008). DCs also process PAMPs into peptides for presentation onto major histocompatibility $(m h c)$ molecules to T cell receptors $(t c r)$. Thus DCs are crucial for both adjuvant effects and innate/adaptive immune responses (Figure 1).

Although most PAMP-derived vaccine adjuvants act through TLRs on mammalian DCs (Figure 1), other internal adjuvants, such as hmgb1 released from lysed cells, exert their action through cell damage molecules (Lambrecht et al., 2009). Artifitial TLR-independent adjuvants, such as those derived from particulate compounds administered together with mammalian vaccines (mineral salts, liposomes, microparticles, saponins, and emulsions) either increase antigen persistence or uptake by DCs. Traditionally, vaccine adjuvants have been empirically identified as enhancers of antibody responses to a co-administered antigen. However, new adjuvant candidates have also been found among molecules of the signalling cascades of DC activation. According to a recent review (Secombes, 2008), the molecules with potential capacity to act as fish vaccine adjuvants might be found among: i) cytokine/chemokine molecules; ii) co-stimulatory cluster differentiation $(c d)$ antigen receptors; and iii) blocking molecules, which might inhibit negative regulators. Microarray analysis of rhabdoviral fish immunizations have identified some of these molecules, as it will be reviewed here.

\section{Microarrays in the study of the flatfish/HRV/VHSV models}

Traditional sequencing, annotation and estimation of frequencies of each rhabdovirallyinduced transcript in flatfish, is one of the strategies designed to identify genes transcribed after rhabdoviral infections (pathogen-induced gene approach)(Aoki et al., 2011). Thus, the first attempts to identify HRV-induced genes were made in the Japanese flounder Paralichthys olivaceus by sequencing 300-596 expressed sequence tag (EST) clones from leukocytes 2-5 days after infection. The frequencies of each EST were estimated within a short 1 to 10 range (Aoki et al., 1999; Nam et al., 2000). 


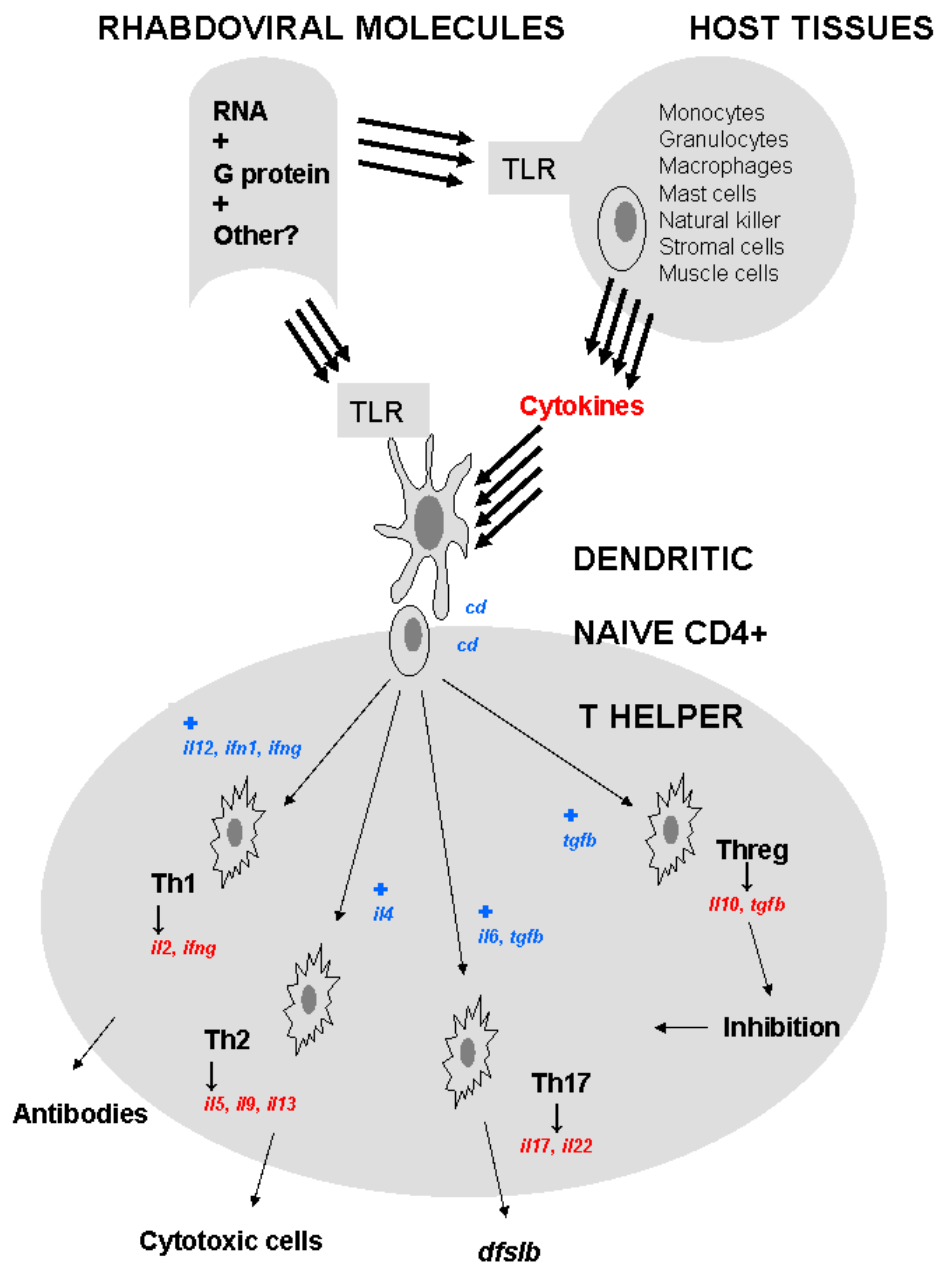

Fig. 1. Scheme of possible mechanisms of adjuvanticity. Modified from several published schemes (De Gregorio et al., 2009; Manicassamy \& Pulendran, 2009; Secombes, 2008). External incoming or internally synthesized rhabdoviral molecules (dsRNA, glycoprotein G, other viral proteins, etc) activate dendritic cells (DCs). These recognize rhabdoviral molecules and are activated either through toll-like receptors (TLRs) or cytokines produced by other cells (monocytes, granulocytes, macrophages, mast cells, natural killer cells, stromal cells, muscle cells, etc). Each combination of rhabdoviral molecules induces simultaneous stimulation of DCs to induce the expression of secreted cytokines and costimulatory membrane $c d s$. The induced membrane $c d s$, together with other signals (blue), induce differentiation of $c d 4+$ cells to T helper cells (Th1, Th2, Th17 and/or Threg). Each differentiated Th cell produces a series of cytokines (red), which are required to make antibodies, cytotoxic lymphocytes, antimicrobial peptides and molecules involved in the regulation of other Ths. Theoretically, any of the up- or down-regulatory molecules that increase defensive responses could be candidate molecular adjuvants for vaccines. 
The new mass-sequencing technologies, such as those offered by the Genome Sequencer FLX (454 Life Sciences, Branford, CT, USA), Illumina Solexa (Illumina Inc., San Diego, CA, USA) or ABI SOLiD (Applied Biosystems, Foster City, CA, USA), could improve the pathogen-induced transcript frequency-estimation strategy. Thus the mass-sequencing technologies produce millions of sequences per run, facilitating significant statistical data for the quantitation of each sequence frequency. However correct annotation of such a mass of new sequences continues to be a problem (Goetz \& MacKenzie, 2008). For instance, of 58 million cDNA sequences of $~ 100 \mathrm{bp}$ from largemouth bass, only 31391 unique sequences could be annotated (Garcia-Reyero et al., 2008). Although, the recent production of longer sequence sizes (200-400 bp), will facilitate their annotation, comparison of transcripts from many samples by this ultra-high-throughput sequencing technology is still not economically feasible. Massive sequencing could be used as a first approach, while a more focused microarray developed with selected genes could then be used for quantification of larger numbers of samples (Goetz \& MacKenzie, 2008).

Japanese flounder EST-derived cDNA microarrays were applied to in vitro kidney cell cultures 3-6 h after HRV infection (Kurobe et al., 2005). The number of expressed transcripts changed in $20.8 \%$ of the genes after HRV infection. The 91 immune-related genes of the microarray were preliminarily categorized into 8 clusters on the basis of their known pattern of gene expression. After $3 \mathrm{~h}$ of HRV infection, several genes included in the chemotaxis, apoptosis, cell growth and antigen-presenting clusters were increased while the expression of some genes, including $m x$, decreased. Among the genes of unknown function that changed after HRV infection, 13 showed a similar response profile to that of the genes of known function mentioned above. This observation may be indicative of their association.

Improved versions of Japanese flounder EST-derived cDNA microarrays (779 spots containing 228 immune-related genes) were used for in vivo differential gene expression after intramuscular injection of DNA vaccines containing the G gene of VHSV (Byon et al., 2006) and/or HRV (Yasuike et al., 2007). The differential expression of their transcripts was studied in kidney tissue 1, 3, 7 and 21 days after vaccination. The greatest number of differentially expressed genes (Figure 2) was observed 3 days after injection $(91.4 \%$ were increased, of which $31 \%$ were known genes). Genes with increased expression/transcription include those related to the non-specific immune responses, such as $t n f, i l 1 r, c c r$, and $m x$, transcription factors, and even a few genes associated with the late specific antibody response, such as $c d 20$. Many interferon-inducible genes including $m x$ and interferon regulatory genes were the most strongly induced genes 3 and 7 days after injection. The expression of a number of unknown genes was also increased(Aoki et al., 2011). Among these, the LB3(8) gene increased a maximum of 56-fold 3 days after infection and then remained increased during one week (Byon et al., 2005).

Later versions of the Japanese flounder EST-derived cDNA microarrays of up to 1187 unique flounder ESTs (691 identified genes) were then used to compare the injection of recombinant $G$ protein (non-protective) with the $G$ gene (protective) (Byon et al., 2006). A number of IFN-related genes (including the unknown LB3(8)) and $m x$ increased 7 days after injection, thereby confirming the observations made in previous studies using reverse transcriptase-quantitative polymerase chain reaction (RT-qPCR) (Acosta et al., 2005; Robertsen, 2008). Further studies included differential gene expression in kidneys from Japanese flounder injected with the HRV G gene (protective) in comparison with the $N$ gene 


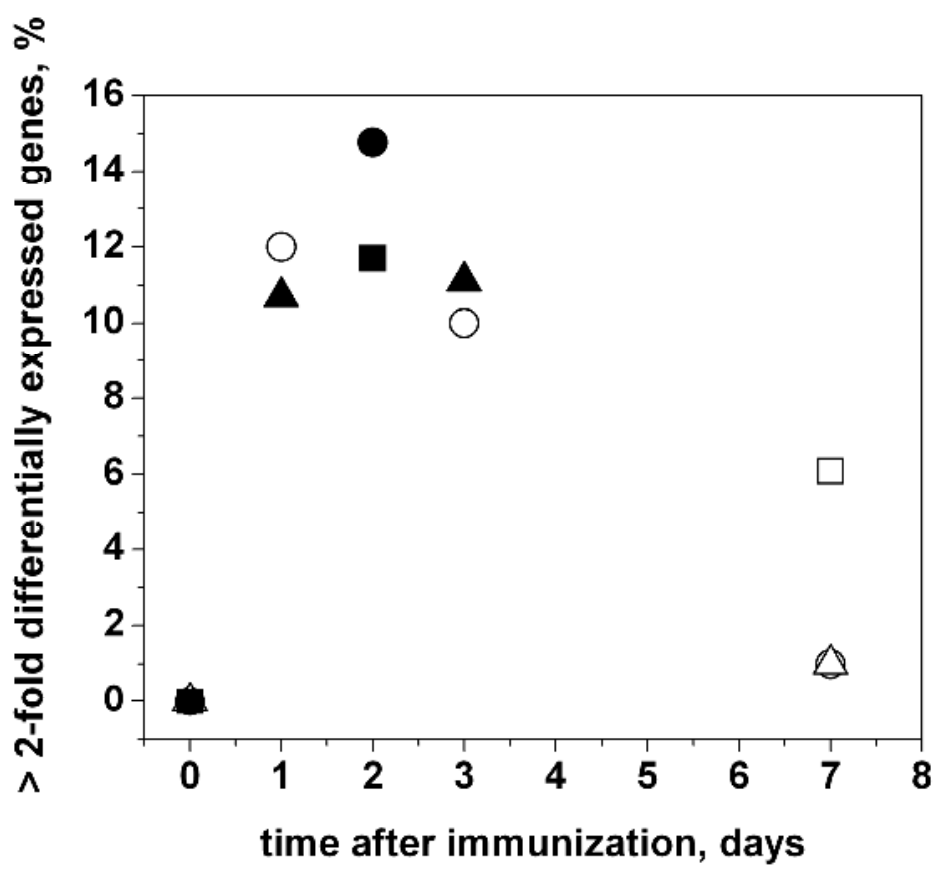

Fig. 2. Number of differentially expressed genes after rhabdoviral immunization. Genes with increase expression were defined as those genes with more than 2-fold increase in expression. ip, intraperitoneal injection. im, intramuscular injection. imm, immersion. Flounder, Japanese flounder, Paralichthys olivaceus. Trout, rainbow trout, Oncorhynchus mykiss. Zebrafish, Danio rerio. *, number of unique sequences or features and type of microarray (cDNA or oligo DNA). $\mathrm{HRV}$, hirame rhabdovirus. IHNV, infectious haematopoietic necrosis virus. VHSV, viral haemorragic septicemia virus. $\boldsymbol{\Lambda}$, infection-by-injection of trout with the IHNV G gene and expression on head kidney with $\mathrm{p}<0.01$ (MacKenzie et al., 2008). $\bullet$, Infection-by-immersion of zebrafish with VHSV and expression on fins (Encinas et al., 2010). ., VHSV infection-byimmersion of zebrafish and expression in internal organs (head kidney, liver and spleeen) (Encinas et al., 2010). $\square$, Injection of trout with the IHNV G gene and expression in muscle tissue with $p>0.01$ (Purcell et al., 2006b). $\Delta$, injection of Japanese flounder with the HRV G gene and expression in head kidney (Yasuike et al., 2007). $\odot$, Injection of Japanese flounder with the VHSV G gene and expression in head kidney (Byon et al., 2006).

(non protective). Results confirmed that the IFN-inducible genes, LB3(8) and $m x$, were also increased 7 days after vaccination but only when the $G$ gene was used (Yasuike et al., 2007). Furthermore, it was shown that the LB3(8) gene has an homologous domain to that of a mammal IFN-inducible protein. Thus, this gene is an example of how new genes involved in rhabdoviral immunization can be discovered by the microarray approach.

However, in all the series of experiments on flounder commented above, only transcripts from pooled organs from 3-5 fish were compared. Biological replicates were not reported and therefore statistical biological variation could not be estimated. Furthermore, the number of genes in the microarrays were relatively small and their collected data has not 
been deposited in any known banks to allow for independent or comparative analysis. Nevertheless, two main conclusions can be drawn from these experiments. Firstly, the largest number of differentially expressed kidney genes after fish rhabdoviral (VHSV or HRV) immunization-by-injection occurs 2-3 days after vaccination (Figure 2) and, secondly, IFN-induced gene responses are stimulated after 3-7 days (Byon et al., 2005; Byon et al., 2006; Kurobe et al., 2005).

In these earliest experimentations, microarrays based on cDNAs (100-500-mer) rather than oligos (60-70-mer) were used. Because one of the greatest concerns with cDNA arrays is cross-hybridization between similar genes or between repeated elements of different genes as a result of the pseudotetraploidy of many fish, the use of oligo microarrays would increase specificity (von Schalburg et al., 2008). However, in contrast to cDNA microarrays, oligo microarrays have a poorer performance when used for other related species. The current tendency appears to favour the use of the former. Thus, by using oligo microarrays, the printing layouts, total number of sequences and number of sequence replicates can be modified to meet any formats. Furthermore, oligo microarrays do not required maintenance of collections of bacterial clones coding for cDNAs. In addition, oligonucleotides can be selected and used in a range of various formats suitable for each experimental design. Improved sensitivity, increased dynamic range, lower variance and fewer outliers have also been demonstrated when using oligo rather than cDNA microarrays. Correlation between cDNA and oligo microarray results has been demonstrated, although some discrepancies have also been reported (Salem et al., 2008). High density oligo microarrays have been developed in other fish such as salmonids (von Schalburg et al., 2008), rainbow trout (Dios et al., 2008; Salem et al., 2008) and zebrafish (Cameron et al., 2005) (Table 1).

\section{Microarrays in the study of the salmonid/IHNV/VHSV models}

Large-scale genomic projects for salmon have been initiated by groups in Canada, the USA, the UK, Norway and France. As a result there are many physical and genetic maps, large collections of ESTs and a growing number of genomic sequences and derived microarrays. Thus three projects have developed salmonid microarrays. The first salmonid 16K cDNA microaarray appeared in 2004. This array was developed by the Genomic Research on Atlantic Salmon Project (GRASP)(von Schalburg et al., 2005a) and led to the most recent 32K cDNA (von Schalburg et al., 2008) and the first 5K oligo DNA of 70-mer (Koop et al., 2008) microarrays. The high sequence similarity ( $86 \%$ ) between salmonids ( 9 genera and 68 species) indicates that cDNA microarrays may be suitable for studies involving any member of this fish family. Transcriptome Analysis of Important Traits of Salmon (TRAITS) and the Norwegian Salmon Genome Project (SGP) also developed a 16K cDNA microarray (http://www.abdn.sfirc/salmon) based on two independent collections of their bacterial clones kept in ARK, Genomics Facility at Roslin Institute, UK and at SGP Genetics Laboratory at the University of Oslo, respectively. The TRAITS-SGP cDNA array was obtained from ESTs from 15 tissues (pathogen-induced libraries, trait-specific substractive EST, starvation-induced libraries, diet-response libraries, smoltification-response libraries and well-known genes). This array was conceived as a preliminary tool to develop an oligo microarray for routine health monitoring of Atlantic salmon. The first results found some artefactual expression patterns caused by cross-hybridization of similar transcripts and underlined the greater relevance of biological over technical replicates (Taggart et al., 2008). 
By using all the tentative consensus sequences available at the Rainbow Trout Gene Index (RTGI) data base, a 37K oligo microarray was constructed (Salem et al., 2008), which is available at Agilent (design number 16271, deposited on the GEO with the GPL6018 number). The new rainbow trout (Oncorhynchus mykiss) high-density, oligonucleotide microarray was developed using 37394 specific 60 -mer oligonucleotide probes assembled from 244984 ESTs from 12 tissues (http://compbio.dfci.harvard.edu/tgi/cgibin/tgi/gimain.pl?gudb1/4r_trout). The specificity of each probe was checked for possible non-specific mRNA cross-hybridization by comparing all individual probes with all rainbow trout transcriptome sequences. Approximately $91 \%$ of the sequences used for this microarray matched a previously annotated sequence in the GenBank.

Few attempts have been made to use these microarrays to study the rhabdoviral immunization of salmonids. In homozygous trout, the $16 \mathrm{~K}$ cDNA GRASP microarray was used to profile 7-day muscle transcripts after intramuscular injection of the IHNV G gene (Purcell et al., 2006a; von Schalburg et al., 2005b). After immunization, irf3, $m x$, vig1, and vig8 transcripts were increased (Purcell et al., 2006a). Genes associated with antigenpresenting cells, lymphocytes, leukocytes, inflammation, antigen presentation, and interferon pathways were also augmented. The increased levels of transcripts associated with type I IFN pathways in systemic organs (gill, spleen and kidney) were corroborated by RT-qPCR. These observations confirmed that, when intramuscularly injected, the hostexpressed viral G gene induces a systemic non-specific type 1 IFN innate immune response.

Using a $1.8 \mathrm{~K}$ cDNA salmonid microarray, comparison of infection-by-injection with IHNV and attenuated IHNV in rainbow trout after 1 and 3 days showed an IHNV-dependent change in differential transcription in kidney towards adaptive immunity genes (MacKenzie et al., 2008). Thus, the rapid spread of the IHNV infection inhibited tnfa, mhc1, and several other gene markers while favouring $m h c 2$ and ig responses. The molecular mechanism for the development of late (months) specific cytotoxic T or B cell-mediated humoral responses has not been addressed by means of microarrays (Kurath, 2008; Kurath et al., 2006).

More recently, trout families with low (32\% survival following challenge) and high susceptibility to VHSV (18\% survival following challenge) were infected with VHSV by bath exposure and transcriptional data from internal organs were analyzed with the 16K GRASP microarray from day 3 post-challenge (Jorgensen et al., 2011). In total, 939 genes were differentially expressed between infected and non-infected fish. The genes increased in infected fish belonged to the following categories: stress and defence response, NFkappaB signal transduction, response to non-self, antigen processing and presentation, and proteasome complexes. Most were also increased among the 642 differentially expressed genes in the low-susceptibility trout family but not among the 556 differentially expressed genes in the high-susceptibility family. These results suggest that the innate immune system of internal organs plays a crucial role in eliciting an effective immune response to VHSV infection in rainbow trout (Jorgensen et al., 2011).

\section{Microarrays in the study of the VHSV/zebrafish model}

The zebrafish Danio rerio is one of the most suitable models in which to carry out microarray studies because, compared to other fish, its genome sequence is one of the most advanced. Furthermore, $\sim 40 \mathrm{~K}$ annotated quantitative polymerase chain reaction (qPCR) arrays and 
annotated oligo microarrays are available. In addition, large-scale experimentation with zebrafish is easier than with other fish models and zebrafish are susceptible to several viruses, most of these belonging to the fish rhabdoviral family (Sullivan \& Kim, 2008). Of these, VHSV (Novoa et al., 2006) was chosen in a recent study using microarrays (Encinas et al., 2010) over IHNV (LaPatra et al., 2000), snake-head rhabdovirus (SHRV)(Phelan et al., 2005) and spring viremia of carp (SVC)(Sanders et al., 2003), because only in the VHSV/zebrafish model have infection-by-immersion (the natural route of infection) and successful vaccination been described (Novoa et al., 2006).

Damage and epithelial cell death immediately after VHSV infection in the surface portals of entry of these viruses, such as the fins (Harmache et al., 2006), should alert surrounding cells to promote epithelial cell division to replace dead cells, recruit inflammatory cells to the infection site, and send signals to internal immune organs. However, viral-induced signals to inhibit the most relevant host responses have also been detected. Detection of natural early responses may contribute to identifying vaccine adjuvants. Thus, the expression of the 636 immune-related transcripts that were increased after VHSV infection, as estimated by hybridization to oligo microarrays (confirmed by RT-qPCR arrays), was higher in fins than in organs. In contrast, the number of decreased transcripts was higher in organs than in fins (Figure 3). Therefore, an upregulated response of immune-related genes was greatest in fin tissues, while a downregulated response was most detected in the internal organ responses. The latter might be targets of viral inhibitory signals early after infection (Encinas et al., 2010). These results showed that 2 days after infection-by-immersion, VHSV had not yet caused an strong response from zebrafish internal organs, which contrasts with reports in other fish at later times after infection-by-injection (such as ifn $1, m x, i l 1 b, \operatorname{tnfa}$, etc) (Acosta et al., 2006; Samuel, 2001; Tafalla et al., 2007; Tafalla et al., 2005) or infection-by-immersion (Jorgensen et al., 2011; Zhang et al., 2009).

The zebrafish are refractory to rhabdoviral infection-by-immersion at high temperatures or without acclimatation to low temperatures with IHNV (LaPatra et al., 2000), VHSV (Novoa et al., 2006) or SVC (Sanders et al., 2003). Therefore, a temperature-dependent response mechanism(s) that inhibits rhabdoviral infection and spread may occur. While these preliminary findings shed some light on the earliest effects of VHSV infection at the molecular level, some of the new immune-related genes identified might be suitable candidate adjuvants for fish vaccines (Rajcani et al., 2005; Secombes, 2008).

\section{Comparative microarray study of fish/rhabdoviral models}

To best detect innate immune responses, early times after rhabdoviral infection should be studied. Thus, according to the data obtained from flatfish, salmonid and zebrafish studies, the maximal number of $>2$-fold differentially expressed genes in microarrays was detected 2-3 days after rhabdoviral infection (Aoki et al., 1999; Byon et al., 2005; Byon et al., 2006; Kurobe et al., 2005; MacKenzie et al., 2008; Nam et al., 2000; Purcell et al., 2006a; von Schalburg et al., 2005b; Yasuike et al., 2007) (Figure 2).

Table 2 shows a list of some of the differentially transcribed immune-related genes detected using microarrays after rhabdoviral immunization, independently of immunization mechanism, fish species, rhabdoviruses and organs. Among the gene list, ifn and irf-related genes were expected to be present; however, their presence was scarce. As with many other 


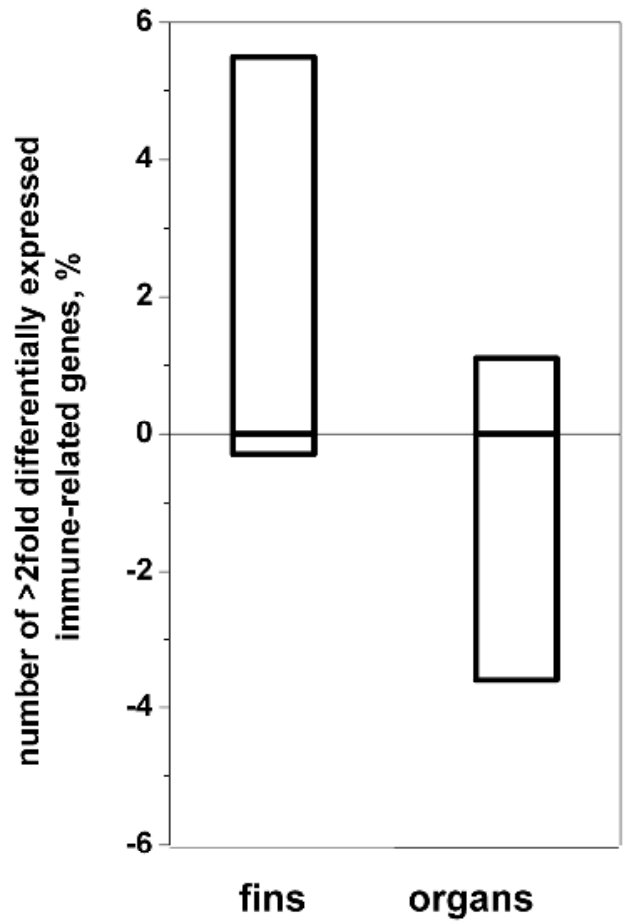

Fig. 3. Comparison of the number of differentially expressed genes 2 days after VHSV infection in zebrafish fins and organs (modified from Encinas et al., 2010). Groups of 10 zebrafish (Danio rerio) were infected with VHSV. To perform the hybridization to oligo microarrays, 636 selected immune-related sequences from the $44 \mathrm{~K}$ microarray (Appligene) were used to analyze mRNA levels. Normalization was made with the ribosomal phosphoprotein $\mathrm{p} 0(\mathrm{rplp} 0)$ gene. Folds were calculated by the following formula: mRNA levels in VHSV-infected zebrafish / mRNA levels in non-infected zebrafish. The total number of genes increasing $(+)$ or decreasing $(-)$ expression $>2$-fold and $p<0.05$ was represented as the percentage of the total number of immune-related genes assayed $(n=4)$. Percentages were calculated by the formula, $100 \mathrm{x}$ the number of differentially expressed genes / total number of immune-related genes assayed (Encinas et al., 2010).

viruses and host species, an increase in ifn 1 expression is one of the first responses to the injection of any DNA vaccine (Acosta et al., 2006; Samuel, 2001) and to rhabdoviral infections (Samuel, 2001; Theofilopoulos et al., 2005).

Transcripts encoding several forms of il17 were detected as differentially expressed only in one of the studies using microarrays (Encinas et al., 2010). Il17 is produced by T helper 17 (Th17) cells (Figure 1) and acts together with il22 on epithelial cells (Trifari et al., 2009) and other types of skin cells to trigger $i l 1 b$ and tnf. These responses induce neutrophil/macrophage recruitment in epithelial surfaces (Qiu et al., 2009), stimulate keratinocytes (Nograles et al., 2008) and increase the production of antimicrobial peptides such as hepcidin (hamp1) and defensin B like-2 (defbl2). Both hamp1 and defbl2 were found 


\begin{tabular}{|c|c|c|}
\hline Gene classes & Genes & References \\
\hline Interleukins & $i l 17$ & (Encinas et al., 2010) \\
\hline$\&$ & $i l 1 r$ & (Kurobe et al., 2005) \\
\hline \multirow[t]{2}{*}{ Receptors } & $i l 8 r$ & (Nam et al., 2000) \\
\hline & $i l 1 b$ & (Encinas et al., 2010) \\
\hline Interferon - & irf1 & (Kurobe et al., 2005) \\
\hline related & $m x$ & (Yasuike et al., 2007) \\
\hline \multirow[t]{4}{*}{ molecules } & isg 15,56 & (Yasuike et al., 2007) \\
\hline & iip56 & (Byon et al., 2006) \\
\hline & iip54 & (Aoki et al., 1999) \\
\hline & ifn3 & (Encinas et al., 2010) \\
\hline $\begin{array}{l}\text { Major } \\
\text { Histocompatibility }\end{array}$ & mhc1 & $\begin{array}{l}\text { (Aoki et al., 1999; Byon et al., 2006; Encinas et al., 2010; } \\
\text { MacKenzie et al., 2008) }\end{array}$ \\
\hline Complex & $m h c 2$ & $\begin{array}{l}\text { (Aoki et al., 1999; Byon et al., 2006; Kurobe et al., 2005; } \\
\text { MacKenzie et al., 2008; Nam et al., 2000) }\end{array}$ \\
\hline Antimicrobial & hamp1 & (Aoki et al., 2011; Encinas et al., 2010) \\
\hline peptides & defbl2 & (Encinas et al., 2010) \\
\hline $\begin{array}{l}\text { Chemokines \& } \\
\text { receptors }\end{array}$ & ccr & (Byon et al., 2006; Kurobe et al., 2005) \\
\hline Complement & $c 3$ & (Byon et al., 2006; Encinas et al., 2010) \\
\hline \multirow[t]{2}{*}{ components } & $\begin{array}{l}c f b / c 2 b, c r p p, c 3 b, b f b, \\
c f h p, c l u, c 6, c 8 a, c 8 g, \\
c 9, c 1 q\end{array}$ & (Encinas et al., 2010) \\
\hline & c3ar & (MacKenzie et al., 2008) \\
\hline $\begin{array}{l}\text { High Mobility } \\
\text { proteins }\end{array}$ & $h m g b$ & $\begin{array}{l}\text { (Aoki et al., 1999; Encinas et al., 2010; MacKenzie et al., } \\
\text { 2008; Nam et al., 2000) }\end{array}$ \\
\hline G proteins & $g n b$ & (Byon et al., 2006; Encinas et al., 2010) \\
\hline \multirow{4}{*}{$\begin{array}{l}\text { TNF-related } \\
\text { molecules }\end{array}$} & $\operatorname{tnf}$ & (Byon et al., 2006; Encinas et al., 2010; Kurobe et al., 2005) \\
\hline & tnfr & (MacKenzie et al., 2008) \\
\hline & $\operatorname{tnfr} 1$ & (Nam et al., 2000) \\
\hline & tnfr2-traf & (Kurobe et al., 2005; Nam et al., 2000) \\
\hline Toll-like & tlr2 & (Kurobe et al., 2005) \\
\hline \multirow[t]{3}{*}{ receptors } & tlr5 & (Encinas et al., 2010) \\
\hline & $\operatorname{tlr} 7$ & (Encinas et al., 2010) \\
\hline & tlr9 & (Encinas et al., 2010) \\
\hline Immunoglobulin & $i g h$ & (Byon et al., 2006; Encinas et al., 2010) \\
\hline \multirow[t]{3}{*}{ chain domains } & $i g h z$ & (Encinas et al., 2010) \\
\hline & $i g l$ & (Aoki et al., 1999; MacKenzie et al., 2008) \\
\hline & sid4 & (Encinas et al., 2010) \\
\hline
\end{tabular}

Table 2. Some of the fish immune-related genes differentially transcribed in microarray studies after rhabdoviral immunization. Independently of fish species, rhabdovirus, organ and time after immunization, annotated genes with a differential expression $>2$ fold were searched in the original papers and some of the most common were ordered on the basis of gene classes and listed in the table. 
to be differentially expressed in some studies (Table 2) (Liang et al., 2006; Yu \& Gaffen, 2008).

Differentially upregulated transcripts of $i l 12$ were detected in a zebrafish fin study (Encinas et al., 2010). In that context, il12 is crucial because it has been widely described as a vaccine adjuvant in mammals (Bliss et al., 1996; Chong et al., 2007; Hirao et al., 2008; Stevceva et al., 2006), specifically increasing protective mucosal immunity (Arulanandam et al., 1999; Wright et al., 2008) to viral infection (Hancock et al., 2000; Jacobson et al., 2006; Skeen et al., 1996; Zheng et al., 2005). However, ill2 has not been tested in fish.

Co-stimulatory cell membrane cluster differentiation antigens $(c d)$ molecules responsible for the antigen-presenting cell interactions with $\mathrm{T}$ cells were not differentially expressed, except those belonging to $m h c 1$ and $m h c 2$ molecules (Table 2). Nevertheless, the use of $c d s$ as vaccine adjuvants has been described for the $c d 154$ gene in zebrafish (Gong et al., 2009); the reasoning being that co-expression of $c d s$ with antigen in the same cell might accelerate specific immune responses. Thus, specific antibody responses obtained using $c d 154$ and the pMCV1.4 plasmid coding for the G gene of VHSV (Ruiz et al., 2008) were increased 3-4-fold with respect to the plasmid alone (Gong et al., 2009).

Transcripts of $c 3$ and $c 3 a$ were differentially expressed in salmonid and flatfish internal organs after immunization-by-injection while many more complement components $(c f b / c 2 b$, crpp, $b f b, c f h p, c l u$ and $c 6$ and $c 8 a)$ were found in zebrafish fins after infection-by-immersion (Encinas et al., 2010). The use of $c 3$ derivatives (c3a, c3d, c4a and $c 5 a$ ) (Green et al., 2002; Ross et al., 2001; Sunyer et al., 2005; Villiers et al., 1999a; Villiers et al., 1999b) as vaccine adjuvants has been reported in mammals but not in fish. A possible relationship between $c 3$ trout genetic polymorphism and VHSV resistance (not confirmed by genetic evidence) (Slierendrecht et al., 1993; Slierendrecht et al., 1995; Slierendrecht et al., 1996) may require further physiological studies.

TLRs, immunoglobulin chains, TNF -related molecules, and high mobility proteins were also found amongst the differentially expressed genes in several studies using microarrays and thus might deserve some consideration as adjuvant candidates (Table 2).

\section{Future research}

Microarray and mass sequencing technologies have opened up new avenues to analyze gene expression profiles. The data obtained by these technologies might facilitate the discovery of new immune-related genes (immunogenomics), clarify the molecular mechanisms of immunity and identify new candidates for vaccine adjuvants. Nevertheless, some problems remain in the application of these technologies to the amelioration of fish rhabdoviral vaccines. For instance there is a need to improve comparison of the data obtained from different models, to complete present gene annotations, to confirm transcriptional data with protein data and to develop mathematical models to facilitate interpretation of the abundant data.

In addition, the number of immune-related genes on zebrafish, trout, salmon, human and mice microarrays (Table 3), shows that more fish immune-related genes might have to be included in future microarray designs. The number of immune-related genes are still much lower in other cultured fish species (turbot, sea bream, sea bass, etc). 


\begin{tabular}{|c|c|c|c|c|c|c|c|}
\hline \multirow[b]{2}{*}{ Immune-related } & \multicolumn{2}{|c|}{ Zebrafish } & \multirow{2}{*}{$\begin{array}{l}\text { Trout } \\
\text { AGIt }\end{array}$} & \multicolumn{2}{|c|}{ Salmonids } & \multirow{2}{*}{$\begin{array}{c}\text { Human } \\
\text { AFYh } \\
\text { U133v2.0 }\end{array}$} & \multirow{2}{*}{$\begin{array}{c}\text { Mouse } \\
\text { AFYm } \\
430 \mathrm{v} 2.0\end{array}$} \\
\hline & AFYz & AGIz & & GRAs & TRAs & & \\
\hline key words & $14 \mathrm{~K}$ & $45 \mathrm{~K}$ & $37 \mathrm{~K}$ & $36 \mathrm{~K}$ & $36 \mathrm{~K}$ & $47 \mathrm{~K}$ & $39 \mathrm{~K}$ \\
\hline interferon & 19 & 53 & 62 & 92 & 42 & 103 & 91 \\
\hline chemokine & 14 & 36 & 29 & 56 & 10 & 104 & 100 \\
\hline interleukin & 8 & 57 & 62 & 49 & 40 & 187 & 142 \\
\hline cytokine & 13 & 43 & 28 & 49 & 13 & 87 & 68 \\
\hline defensin & 1 & 3 & 2 & 0 & 1 & 29 & 32 \\
\hline antiviral & 0 & 2 & 1 & 0 & 0 & 9 & 5 \\
\hline LPS & 0 & 0 & 0 & 0 & 2 & 2 & 7 \\
\hline $\begin{array}{l}\text { histocompatibili } \\
\text { ty }\end{array}$ & 13 & 18 & 13 & 59 & 3 & 76 & 74 \\
\hline MHC & 2 & 16 & 70 & 375 & 433 & 10 & 4 \\
\hline viral & 40 & 73 & 29 & 16 & 8 & 171 & 96 \\
\hline $\mathbf{M x}$ & 0 & 1 & 0 & 0 & 1 & 0 & 0 \\
\hline complement & 28 & 79 & 168 & 88 & 53 & 129 & 102 \\
\hline $\begin{array}{l}\text { immunoglobuli } \\
\text { n }\end{array}$ & 14 & 53 & 116 & 54 & 46 & 294 & 156 \\
\hline Toll & 3 & 22 & 5 & 17 & 12 & 39 & 31 \\
\hline TNF & 15 & 22 & 7 & 13 & 3 & 7 & 38 \\
\hline macrophage & 5 & 11 & 22 & 25 & 25 & 34 & 36 \\
\hline lymphocyte & 2 & 15 & 22 & 14 & 8 & 49 & 52 \\
\hline neutrophil & 2 & 4 & 0 & 4 & 7 & 11 & 7 \\
\hline leukocyte & 6 & 15 & 12 & 18 & 4 & 50 & 21 \\
\hline cytotoxic & 5 & 5 & 14 & 3 & 4 & 30 & 22 \\
\hline natural killer & 3 & 0 & 3 & 2 & 5 & 19 & 8 \\
\hline $\mathrm{T}$ cell & 13 & 64 & 63 & 59 & 14 & 88 & 112 \\
\hline B cell & 20 & 42 & 29 & 36 & 11 & 102 & 97 \\
\hline dendritic & 0 & 3 & 15 & 0 & 3 & 0 & 0 \\
\hline TOTAL & 226 & 637 & 772 & 1029 & 748 & 1630 & 1301 \\
\hline
\end{tabular}

Table 3. Estimation of the numbers of immune-related genes in fish microarrays compared to human and mouse. Microarrays vary in the number of probes per gene, and gene nomenclatures. Many fish genes might be duplicated variants (due to pseudotetraploid genomes or transposon variations) and arrays may use different genes and/or cDNA or oligos per gene. All these facts make comparison of microarray platform gene contents difficult. The use of immune-related key words to preliminarily compare the relative abundance of the genes might serve for a first estimation. The future should bring about the use of a common languages such as gene abbreviations following the HUGO Gene Nomenclature Committee for human orthologues (http:/ / www.genenames.org) and/or UniGene entries ( http://www.ncbi.nlm.nih.gov/unigene). Genes should be also grouped by functional categories such as by using gene ontology (GO annotation for the immune system http:/ / www.geneontology.org/GO.immunology.shtml) or the clusters of orthologous genes (COG, http://www.ncbi.nlm.nih.gov/COG). 


$\begin{array}{ll}\text { AFYz (AFFYMETRIX, zebrafish) } & 14 \mathrm{~K}, \sim 15 \text { oligos } 25 \text {-mer/gen (Santa Clara, CA,USA). } \\ \text { AGIz (AGILENT, zebrafish vs2) } & 45 \mathrm{~K}, 1 \text { oligo 60-mer/gen (Palo Alto,CA, USA) } \\ \text { AGIt (AGILENT, trout) } & 37 \mathrm{~K}, 1 \text { oligo } 60 \text {-mer/gen } \\ \text { GRAs (GRASP, salmonids) } & 36 \mathrm{~K}, 1 \text { cDNA/gen } \\ \text { TRAs (TRAITS-SGP, salmonids) } & 36 \mathrm{~K}, 1 \text { cDNA/gen } \\ \text { AFYh (AFFYMETRIX, human) } & 47 \mathrm{~K}, \mathrm{U} 133 \text { plus v2.0 } ~ 11 \text { oligos } 25-\text { mer /gen } \\ \text { AFYm (AFFYMETRIX, mouse) } & 39 \mathrm{~K}, 430 \text { v2.0 11 oligos 25-mer/gen }\end{array}$

The use of microarray technology stems from the availability of genome, mRNA and EST (http://www.ncbi.nlm.nih.gov/dbEST) sequences to build representative annotated (geneidentified sequences) microarrays. For most commertial fish species, there is a lack of information on the annotated genome or known mRNA sequences and thus most microarrays used for these species mostly apply EST sequences. However, correct and complete annotation continues to be a bottleneck.

At present, it is quite difficult to compare data from distinct microarrays, even between salmonid microarrays such as GRASP, TRAITS-SGP and RTGI. We consider that reanalysis of the data deposited in data banks, for instance by the NCBI Gene Expression Omnibus (GEO) (http://www.ncbi.nlm.nih.gov/geo), to identify similar or identical genes should be undertaken.

For the most studied fish species, such as zebrafish, trout and salmon, identified mRNA sequences present in current GenBanks can alternatively be used to design focused microarrays enriched in some gene classes. For instance, the zebrafish and trout microarrays that are currently available omit a number of immune-related genes, the number of which vary depending on each microarray. A possible alternative to this problem in fish species for which abundant annotated mRNA sequences are held in GenBanks is to search for keyword-selected sequences to build up the corresponding microarrays.

One example of using some of the most obvious keywords corresponding to immunerelated genes for the trout O. mykiss and the zebrafish D. rerio is shown in Table 4. Thus, this table shows that the number of some immune-related genes extracted from GenBank data are 2-24-fold higher than their corresponding numbers in the microarrays of trout and zebrafish commertially available. Furthermore, trout and zebrafish $2-4 \mathrm{~K}$ microarrays designed on unique sequences selected from GenBank immune-related genes (using 50 keywords in GenBanks) are enriched an average of 2-3-fold in immune-related sequences with respect to the more general $37-44 \mathrm{~K}$ commertial alternatives (data not shown). The design of smaller, focused (ie: immune-related) microarrays based on existing GenBank sequences could contribute to making the experiments less expensive and their results easier to interpret.

Although the advent of mass sequencing technologies might soon change this scenario, correct annotation will still require a considerable research effort for most fish species.

Care must be taken not to over interpret differential transcript gene expression. Thus, some rhabdoviral-induced changes might involve protein cleavages (complement $c 3$ ) and/or protein post-translation modifications ( $h m g b 1)$ in which transcriptional control may not be essential. Although in most reports some of the microarray results were confirmed using RT-qPCR, true confirmation would require estimation of its corresponding protein levels by parallel proteomic studies. Thus, although the differential expression of some fin proteins 


\begin{tabular}{lccccc} 
& \multicolumn{2}{c}{ Zebrafish } & & \multicolumn{2}{c}{ Trout } \\
\cline { 2 - 3 } \cline { 5 - 6 } Gene names & $\begin{array}{c}* \text { Available } \\
\text { microarrays }\end{array}$ & GenBank & & $\begin{array}{c}* * \text { Available } \\
\text { microarrays }\end{array}$ & GenBank \\
\hline Interleukin & 88 & 355 & & 47 & 97 \\
Chemokine & 93 & 367 & & 24 & 84 \\
Interferon & 89 & 299 & & 48 & 107 \\
Toll & 41 & 107 & & 8 & 37 \\
Immunoglobulin & 96 & 2207 & & 98 & 1234 \\
MHC & 13 & 320 & & 56 & 411 \\
Vig & 0 & 0 & 6 & 14 \\
\hline
\end{tabular}

* vs 3 of $44 \mathrm{~K}$ oligo microarray of zebrafish (Agilent's ID 26437)

** 37K oligo microarray of trout (Agilents ID 16271) (Salem et al., 2008)

MHC, major histocompatibility complex

Vig, VHSV important genes

Table 4. Comparison of some immune-related genes found in commertially available microarrays with those obtained from GenBank sequences. GenBank at http://www.ncbi.nlm.nih.goc/nuccore

(transferrin, hemopexin, annexin, ATP binding, alpha actin, and kinesin) show a parallel variation with their transcript levels, in most of them, the changes in the differential expression of proteins do not correlate with their corresponding transcript changes (Encinas et al., 2010). This observation suggests that regulation of their expression is not at the transcriptional level, at least in that study. Although correlation of gene and protein expression has been found in some plants (Gallardo et al., 2007; Joosen et al., 2007), most studies found no correlation, including a recent report on individual E. coli cells (Taniguchi et al., 2010). Correlation values comparing gene/protein expression levels in several systems are consistently very low (Hack, 2004), suggesting that mRNA levels are poor indicators of the expression of their corresponding protein. Therefore, the study of mRNA levels is justified only when protein levels cannot be detected by the proteomic approach because of their low concentrations or short lives.

Finally, mathematical modelling of microarray data may shed light on gene changes and be useful for testing new hypotheses. From the first symposium held on 2003 (Petrovsky et al., 2003), some progress has been reported on the use of mathematical modelling for early response genes (Lawrence et al., 2007), whole immune responses (Ahmed \& Hashish, 2006; Kalita et al., 2006), immunity to infectious diseases, including microarray data (Morel et al., 2006) and future perspectives ( $\mathrm{Li}$ et al., 2009; Ta'asan \& Gandlin, 2009). Mathematical modelling is expected to develop further since there are few other alternatives available to interpret the massive amount of information generated by microarrays.

\section{Conclusions}

Novirhabdoviroses are among the few fish viral diseases for which efficacious DNA vaccines are available; however, they continue to affect aquacultured fish worldwide.

Despite DNA vacines being commertial in Canada, the actual method of delivery by fish-tofish intramuscular injection and safety concerns are the major bottle necks to wide 
acceptance of DNA vaccination. In addition, a complete understanding of the molecular events induced after rhabdoviral fish infection and immunization may contribute to improving DNA vaccines not only for rhabdoviroses but also for other fish infections for which there are no current remedies.

Knowledge about infection, vaccination and adjuvant mechanisms in mammal models, together with high throughput genomic techniques, such as hybridization to microarrays (cDNA or oligo, wide or focused) and new massive sequencing technologies (largely unexplored in fish), offer the opportunity to gather a considerable amount of new transcriptional data in fish models.

Indeed, microarrays have already been used to quantify fish gene expression as well as to discover new genes involved in defense in several fish rhabdovirus models, such as flatfish, salmonid (salmon and trout) and zebrafish.

Genes that show increased transcription after infection (hypothetically signalling internal organs to react against the viral invasion) and also genes whose transcription is inhibited (possibly due to viral shut-off of critical host defences) might help researchers in their quest to identify new adjuvant candidates for fish vaccines.

\section{Acknowledgments}

This work was supported by CICYT projects AGL08-03519-CO4-ACU, AGL2011-28921CO3-02 and INGENIO 2010 CONSOLIDER 2007-00002 awarded by the Ministerio de Ciencia e Innovación of Spain.

\section{References}

Acosta F., Collet B., Lorenzen N. \& Ellis A. E. (2006). Expression of the glycoprotein of viral haemorrhagic septicaemia virus (VHSV) on the surface of the fish cell line RTG-P1 induces type 1 interferon expression in neighbouring cells. Fish $\mathcal{E}$ Shellfish Immunology, Vol. 21, No.2, (n.d.), pp. 272-278

Acosta F., Petrie A., Lockhart K., Lorenzen N. \& Ellis A. E. (2005). Kinetics of Mx expression in rainbow trout (Oncorhynchus mykiss) and Atlantic salmon (Salmo salar L.) parr in response to VHS-DNA vaccination. Fish \& Shellfish Immunology, Vol. 18, No. 1, (n.d.), pp. $81-89$

Ahmed E. \& Hashish A. H. (2006). On modelling the immune system as a complex system. Theory in Biosciences, Vol. 124, No. 3-4, (n.d.), pp. 413-418

Anderson E. D., Mourich D. V., Fahrenkrug S. C., LaPatra S. C., Shepherd J. \& Leong J. C. (1996a). Genetic immunization of rainbow trout (Oncorhynchus mykiss) against infectious hematopoietic necrosis virus. Molecular Marine Biology and Biotechnology, Vol. 5, No. 1, (n.d.), pp. 114-122

Anderson E. D., Mourich D. V. \& Leong J. C. (1996b). Gene expression in rainbow trout (Onchorynchus mykiss) following intramuscular injection of DNA. Molecular Marine Biology and Biotechnology, Vol. 5, No. 1, (n.d.), pp. 105-113

Aoki T., Hirono I., Kondo H., Hikima J. \& Jung T. S. (2011). Microarray technology is an effective tool for identifying genes related to the aquacultural improvement of 
Japanese flounder, Paralichthys olivaceus. Comarative Biochemical Physiology Part D Genomics Proteomics, Vol. 6, No. 1, (n.d.), pp. 39-43

Aoki T., Nam B. H., Hirono I. I. \& Yamamoto E. (1999). Sequences of 596 cDNA Clones $(565,977 \mathrm{bp})$ of Japanese Flounder (Paralichthys olivaceus) Leukocytes Infected with Hirame Rhabdovirus. Marine Biotechnology (NY), Vol. 1, No. 3, (n.d.), pp. 4770488

Arulanandam B. P., O'Toole M. \& Metzger D. W. (1999). Intranasal interleukin-12 is a powerful adjuvant for protective mucosal immunity. Journal of Infectious Disease, Vol. 180, No. 4, (n.d.), pp. 940-949

Bearzotti M., Monnier A. F., Vende P., Grosclaude J., DeKinkelin P. \& Benmansour A. (1995). The glycoprotein of viral hemorrhagic septicemia virus (VHSV): antigenicity and role in virulence. Veterinary Research, Vol. 26, No. 3, (n.d.), pp. 413-422

Bliss J., Maylor R., Stokes K., Murray K. S., Ketchum M. A. \& Wolf S. F. (1996). Interleukin12 as vaccine adjuvant. Characteristics of primary, recall, and long-term responses. Annual New York Academy Sciences, Vol. 795, No.1, (n.d.), pp. 26-35

Boudinot P., Blanco M., de Kinkelin P. \& Benmansour A. (1998). Combined DNA immunization with the glycoprotein gene of viral hemorrhagic septicemia virus and infectious hematopoietic necrosis virus induces double-specific protective immunity and nonspecific response in rainbow trout. Virology, Vol. 249, No. 2, (n.d.), pp. 297-306

Boudinot P., Massin P., Blanco M., Riffault S. \& Benmansour A. (1999). vig-1, a new fish gene induced by the rhabdovirus glycoprotein, has a virus-induced homologue in humans and shares conserved motifs with the MoaA family. Journal of Virology, Vol. 73, No. 3, (n.d.), pp. 1846-1852

Boudinot P., Salhi S., Blanco M. \& Benmansour A. (2001). Viral haemorrhagic septicaemia virus induces vig-2, a new interferon-responsive gene in rainbow trout. Fish $\mathcal{E}$ Shellfish Immunology, Vol. 11, No. 5, (n.d.), pp. 383-397

Byon J. Y., Ohira T., Hirono I. \& Aoki T. (2005). Use of a cDNA microarray to study immunity against viral hemorrhagic septicemia (VHS) in Japanese flounder (Paralichthys olivaceus) following DNA vaccination. Fish $\mathcal{E}$ Shellfish Immunology, Vol. 18, No. 2, (n.d.), pp. 135-147

Byon J. Y., Ohira T., Hirono I. \& Aoki T. (2006). Comparative immune responses in Japanese flounder, Paralichthys olivaceus after vaccination with viral hemorrhagic septicemia virus (VHSV) recombinant glycoprotein and DNA vaccine using a microarray analysis. Vaccine, Vol. 24, No. 8, (n.d.), pp. 921-930

Cameron D. A., Gentile K. L., Middleton F. A. \& Yurco P. (2005). Gene expression profiles of intact and regenerating zebrafish retina. Molecular Vision, Vol. 11, No. 8, (n.d.), pp. 775-791

Chong S. Y., Egan M. A., Kutzler M. A., Megati S., Masood A., Roopchard V., Garcia-Hand D., Montefiori D. C., Quiroz J., Rosati M., Schadeck E. B., Boyer J. D., Pavlakis G. N., Weiner D. B., Sidhu M., Eldridge J. H. \& Israel Z. R. (2007). Comparative ability of plasmid IL-12 and IL-15 to enhance cellular and humoral immune responses elicited by a SIVgag plasmid DNA vaccine and alter disease progression following $\operatorname{SHIV}(89.6 \mathrm{P})$ challenge in rhesus macaques. Vaccine, Vol. 25, No. 26, (n.d.), pp. 49674982 
Craig D. H., Shiratsuchi H. \& Basson M. D. (2009). Increased extracellular pressure provides a novel adjuvant stimulus for enhancement of conventional dendritic cell maturation strategies. Biochemical Biophysical Research Communications, Vol. 387, No. 1, (n.d.), pp. 174-179

De Gregorio E., D'Oro U. \& Wack A. (2009). Immunology of TLR-independent vaccine adjuvants. Current Opinion on Immunology, Vol. 21, No. 3, (n.d.), pp. 339-345

delasHeras A. I., Saint-Jean S. R. \& Pérez-Prieto S. I. (2010). Immunogenic and protective effects of an oral DNA vaccine against infectious pancreatic necrosis virus in fish. Fish $\mathcal{E}$ Shellfish Immunology, Vol. 28, No. 4, (n.d.), pp. 562-570

Diab A. M., Williams T. D., Sabine V. S., Chipman J. K. \& George S. G. (2008). The GENIPOL European flounder Platichthys flesus L. toxicogenomics microarray: application for investigation of the response to furunculosis vaccination. Journal of Fish Biology, Vol. 72, No. 21, (n.d.), pp. 2154-2169

Dios S., Novoa B., Buonocore F., Scapigliati G. \& Figueras A. (2008). Genomic Resources for Immunology and Disease of Salmonid and Non-Salmonid Fish. Reviews in Fisheries Science, Vol. 16, No.1, (n.d.), pp. 119-132

Douglas S. E., Knickle L. C., Williams J., Flight R. M. \& Reith M. E. (2008). A first generation Atlantic halibut Hippoglossus hippoglossus (L.) microarray: application to developmental studies. Journal of Fish Biology, Vol. 72, No. 21, (n.d.), pp. 2391-2406

Einer-Jensen K., Delgado L., Lorenzen E., Bovo G., Evensen O., Lapatra S. \& Lorenzen N. (2009). Dual DNA vaccination of rainbow trout (Oncorhynchus mykiss) against two different rhabdoviruses, VHSV and IHNV, induces specific divalent protection. Vaccine, Vol. 27, No. 8, (n.d.), pp. 1248-1253

Encinas P., Rodriguez-Milla M. A., Novoa B., Estepa A., Figueras A. \& Coll J. M. (2010). Zebrafish fin immune responses during high mortality infections with viral haemorrhagic septicemia rhabdovirus. A proteomic and transcriptomic approach. BMC Genomics, Vol. 11, No. 3, (n.d.), pp. 518-534

Fernandez-Alonso M., Rocha A. \& Coll J. M. (2001). DNA vaccination by immersion and ultrasound to trout viral haemorrhagic septicaemia virus. Vaccine, Vol. 19, No. 11, (n.d.), pp. 3067-3075

Gallardo K., Firnhaber C., Zuber H., Hericher D., Belghazi M., Henry C., Kuster H. \& Thompson R. (2007). A combined proteome and transcriptome analysis of developing Medicago truncatula seeds: evidence for metabolic specialization of maternal and filial tissues. Molecular Cell Proteomics, Vol. 6, No. 12, (n.d.), pp. 21652179

Garcia-Reyero N., Griffitt R. J., Liu L., Kroll K. J., Farmerie W. G., Barber D. S. \& Denslow N. D. (2008). Construction of a robust microarray from a non-model species largemouth bass, Micropterus salmoides (Lacepede), using pyrosequencing technology. Journal of Fish Biology, Vol. 72, No. 11, (n.d.), pp. 2354-2376

Goetz F. W. \& MacKenzie S. (2008). Functional genomics with microarrays in fish biology and fisheries. Fish and Fisheries, Vol. 9, No. 3, (n.d.), pp. 378-395

Gomez-Casado E., Estepa A. \& Coll J. M. (2011). A comparative review on European-farmed finfish RNA viruses and their vaccines. Vaccine, Vol. 29, No. 15, (n.d.), pp. 26572671

Gong Y. F., Xiang L. X. \& Shao J. Z. (2009). CD154-CD40 interactions are essential for thymus-dependent antibody production in zebrafish: insights into the origin of 
costimulatory pathway in helper $\mathrm{T}$ cell-regulated adaptive immunity in early vertebrates. Journal of Immunology, Vol. 182, No. 12, (n.d.), pp. 7749-7762

Green T. D., Newton B. R., Rota P. A., Xu Y., Robinson H. L. \& Ross T. M. (2002). C3d enhancement of neutralizing antibodies to measles hemaglutinin. Vaccine, Vol. 20, No. 1, (n.d.), pp. 242-248

Hack C. J. (2004). Integrated transcriptome and proteome data: the challenges ahead. Brief Functional Genomic Proteomic, Vol. 3, No. 3, (n.d.), pp. 212-219

Hancock G. E., Heers K. M. \& Smith J. D. (2000). QS-21 synergizes with recombinant interleukin-12 to create a potent adjuvant formulation for the fusion protein of respiratory syncytial virus. Viral Immunology, Vol. 13, No. 4, (n.d.), pp. 503-509

Harmache A., Leberre M., Droineau S., Giovannini M. \& Bremont M. (2006). Bioluminescence Imaging of Live Infected Salmonids Reveals that the Fin Bases Are the Major Portal of Entry for Novirhabdovirus. Journal of Virology, Vol. 103, No. 8, (n.d.), pp. 3655-3659

Hirao L. A., Wu L., Khan A. S., Hokey D. A., Yan J., Dai A., Betts M. R., Draghia-Akli R. \& Weiner D. B. (2008). Combined effects of IL-12 and electroporation enhances the potency of DNA vaccination in macaques. Vaccine, Vol. 26, No. 25, (n.d.), pp. 31123120

Iwasaki A. (2007a). Division of labor by dendritic cells. Cell, Vol. 128, No. 3, (n.d.), pp. 435436

Iwasaki A. (2007b). Mucosal dendritic cells. Annual Review of Immunology, Vol. 25, No. 2, (n.d.), pp. 381-418

Jacobson M. A., Sinclair E., Bredt B., Agrillo L., Black D., Epling C. L., Carvidi A., Ho T., Bains R., Girling V. \& Adler S. P. (2006). Safety and immunogenicity of Towne cytomegalovirus vaccine with or without adjuvant recombinant interleukin-12. Vaccine, Vol. 24, No. 25, (n.d.), pp. 5311-5319

Joosen R., Cordewener J., Supena E. D., Vorst O., Lammers M., Maliepaard C., Zeilmaker T., Miki B., America T., Custers J. \& Boutilier K. (2007). Combined transcriptome and proteome analysis identifies pathways and markers associated with the establishment of rapeseed microspore-derived embryo development. Plant Physiology, Vol. 144, No. 1, (n.d.), pp. 155-172

Jorgensen H. B., Sorensen P., Cooper G. A., Lorenzen E., Lorenzen N., Hansen M. H., Koop B. F. \& Henryon M. (2011). General and family-specific gene expression responses to viral hemorrhagic septicaemia virus infection in rainbow trout (Oncorhynchus mykiss). Molecular Immunology, Vol. 48, No. 8, (n.d.), pp. 1046-1058

Kalita J. K., Chandrashekar K., Hans R. \& Selvam P. (2006). Computational modelling and simulation of the immune system. International Journal of Bioinformatics and Research Applications, Vol. 2, No. 1, (n.d.), pp. 63-88

Kim C. H., Johnson M. C., Drennan J. D., Simon B. E., Thomann E. \& Leong J. A. (2000). DNA vaccines encoding viral glycoproteins induce nonspecific immunity and $\mathrm{Mx}$ protein synthesis in fish. Journal of Virology, Vol. 74, No. 15, (n.d.), pp. 7048-7054

Koop B. F., von Schalburg K. R., Leong J., Walker N., Lieph R., Cooper G. A., Robb A., BeetzSargent M., Holt R. A., Moore R., Brahmbhatt S., Rosner J., Rexroad C. E., 3rd, McGowan C. R. \& Davidson W. S. (2008). A salmonid EST genomic study: genes, duplications, phylogeny and microarrays. BMC Genomics, Vol. 9, No. 5, (n.d.), pp. 545-555 
Kurath G. (2008). Biotechnology and DNA vaccines for aquatic animals. Reviews in Science and Technology, Vol. 27, No. 1, (n.d.), pp. 175-196

Kurath G., Garver K. A., Corbeil S., Elliott D. G., Anderson E. D. \& LaPatra S. E. (2006). Protective immunity and lack of histopathological damage two years after DNA vaccination against infectious hematopoietic necrosis virus in trout. Vaccine, Vol. 24, No. 3, (n.d.), pp. 345-354

Kurath G., Purcell M. K. \& Garver K. A. (2007). Fish rhabdovirus models for understanding host response to DNA vaccines. $C A B$ reviews, Vol. 2, No. 1, (n.d.), pp. 1-12

Kurobe T., Yasuike M., Kimura T., Hirono I. \& Aoki T. (2005). Expression profiling of immune-related genes from Japanese flounder Paralichthys olivaceus kidney cells using cDNA microarrays. Developmental Comparative Immunology, Vol. 29, No. 6, (n.d.), pp. 515-523

Lambrecht B. N., Kool M., Willart M. A. \& Hammad H. (2009). Mechanism of action of clinically approved adjuvants. Current Opinion on Immunology, Vol. 21, No. 1, (n.d.), pp. 23-29

LaPatra S. E., Barone L., Jones G. R. \& Zon L. I. (2000). Effects on infectious hematopoietic necrosis virus and infectious necrosis virus infection on hematopoietic precursosrs of the zebrafish. Blood Cell Molecular Diseases, Vol. 26, No. 3, (n.d.), pp. 445-452

LaPatra S. E., Lauda K. A. \& Jones G. R. (1994). Antigenic variants of infectious hematopoietic necrosis virus and implications for vaccine development. Diseases Aquatic Organisms, Vol. 20, No. 1, (n.d.), pp. 119-126

Lawrence S., Tang Y., Frank M. B., Dozmorov I., Jiang K., Chen Y., Cadwell C., Turner S., Centola M. \& Jarvis J. N. (2007). A dynamic model of gene expression in monocytes reveals differences in immediate/early response genes between adult and neonatal cells. Journal of Inflammation (London), Vol. 4, No. 1, (n.d.), pp. 4-14

Li X., Wang Z., Lu T. \& Che X. (2009). Modelling immune system: principles, models, analysis and perspectives. Journal of Bionic Enginneering, Vol. 6, No. 1, (n.d.), pp. 7785

Liang S. C., Tan X. Y., Luxenberg D. P., Karim R., Dunussi-Joannopoulos K., Collins M. \& Fouser L. A. (2006). Interleukin (IL)-22 and IL-17 are coexpressed by Th17 cells and cooperatively enhance expression of antimicrobial peptides. Journal of Experimental Medicine, Vol. 203, No. 10, (n.d.), pp. 2271-2279

Longhi M. P., Trumpfheller C., Idoyaga J., Caskey M., Matos I., Kluger C., Salazar A. M., Colonna M. \& Steinman R. M. (2009). Dendritic cells require a systemic type I interferon response to mature and induce CD4+ Th1 immunity with poly IC as adjuvant. Journal of Experimental Medicine, Vol. 206, No. 7, (n.d.), pp. 1589-1602

Lorenzen E., Einer-Jensen K., Rasmussen J. S., Kjaer T. E., Collet B., Secombes C. J. \& Lorenzen N. (2009). The protective mechanisms induced by a fish rhabdovirus DNA vaccine depend on temperature. Vaccine, Vol. 27, No. 15, (n.d.), pp. 3870-3880

Lorenzen E., Einer-Jensen, K., Martinussen, T., LaPatra, S. E. \& Lorenzen, N. (2000). DNA vaccination of rainbow trout against viral hemorrhagic septicemia virus: a doseresponse and time-course study. Journal of Aquatic Animal Health, Vol. 12, No. 1, (n.d.), pp. $167-180$

Lorenzen N. \& LaPatra S. E. (2005). DNA vaccines for aquacultured fish. Reviews in Science and Technology of the Office of International Epizooties, Vol. 24, No. 1, (n.d.), pp. 201213 
Lorenzen N., Lorenzen E., Einer-Jensen K., Heppell J., Wu T. \& Davis H. (1998). Protective immunity to VHS in rainbow trout (Oncorhynchus mykiss, Walbaum) following DNA vaccination. Fish \& Shellfish Immunology, Vol. 8, No. 4, (n.d.), pp. 261-270

Lorenzen N., Lorenzen E., Einer-Jensen K. \& LaPatra S. E. (2002). Immunity induced shortly after DNA vaccination of rainbow trout against rhabdoviruses protects against heterologous virus but not against bacterial pathogens. Developmental Comparative Immunology, Vol. 26, No. 2, (n.d.), pp. 173-179

MacKenzie S., Balasch J. C., Novoa B., Ribas L., Roher N., Krasnov A. \& Figueras A. (2008). Comparative analysis of the acute response of the trout, $\mathrm{O}$. mykiss, head kidney to in vivo challenge with virulent and attenuated infectious hematopoietic necrosis virus and LPS-induced inflammation. BMC Genomics, Vol. 9, No. 1, (n.d.), pp. 141151

Manicassamy S. \& Pulendran B. (2009). Modulation of adaptive immunity with Toll-like receptors. Seminars in Immunology, Vol. 21, No. 4, (n.d.), pp. 185-193

Martin S. A. M., Collet B., Mackenzie S., Evensen O. \& Secombes C. J. (2008). Genomic tools for examining immune gene function in salmonid fish. Reviews on Fisheries Science, Vol. 16, No. 1, (n.d.), pp. 112-118

McAllister P. E., Fryer J. L. \& Pilcher K. S. (1974). An antigenic comparison between infectious haematopoietic necrosis virus (OSV strain) and the virus of haemorrhagic septicaemia of rainbow trout (Salmo gairdneri) (Denmark strain) by cross neutralization. Journal of Wildlife Diseases, Vol. 10, No. 1, (n.d.), pp. 101-103

McLauchlan P. E., Collet B., Ingerslev E., Secombes C. J., Lorenzen N. \& Ellis A. E. (2003). DNA vaccination against viral haemorrhagic septicaemia (VHS) in rainbow trout: size, dose, route of injection and duration of protection-early protection correlates with Mx expression. Fish \& Shellfish Immunology, Vol. 15, No. 1, (n.d.), pp. 39-50

Morel P. A., Ta'asan S., Morel B. F., Kirschner D. E. \& Flynn J. L. (2006). New insights into mathematical modeling of the immune system. Immunology Research, Vol. 36, No. 13, (n.d.), pp. 157-165

Nam B. H., Yamamoto E., Hirono I. \& Aoki T. (2000). A survey of expressed genes in the leukocytes of Japanese flounder, Paralichthys olivaceus, infected with Hirame rhabdovirus. Developmental Comparative Immunology, Vol. 24, No. 1, (n.d.), pp. 13-24

Nograles K. E., Zaba L. C., Guttman-Yassky E., Fuentes-Duculan J., Suarez-Farinas M., Cardinale I., Khatcherian A., Gonzalez J., Pierson K. C., White T. R., Pensabene C., Coats I., Novitskaya I., Lowes M. A. \& Krueger J. G. (2008). Th17 cytokines interleukin (IL)-17 and IL-22 modulate distinct inflammatory and keratinocyteresponse pathways. British Journal of Dermatology, Vol. 159, No. 5, (n.d.), pp. 10921102

Novoa B., Romero A., Mulero V., Rodriguez I., Fernandez I. \& Figueras A. (2006). Zebrafish (Danio rerio) as a model for the study of vaccination against viral haemorrhagic septicemia virus (VHSV). Vaccine, Vol. 24, No. 31-32, (n.d.), pp. 5806-5816

Pardo B. G., Fernandez C., Millan A., Bouza C., Vazquez-Lopez A., Vera M., Alvarez-Dios J. A., Calaza M., Gomez-Tato A., Vazquez M., Cabaleiro S., Magarinos B., Lemos M. L., Leiro J. M. \& Martinez P. (2009). Expressed sequence tags (ESTs) from immune tissues of turbot (Scophthalmus maximus) challenged with pathogens. BMC Veterinary Research, Vol. 4, No. 1, (n.d.), pp. 37-47 
Petrovsky N., Schonbach C. \& Brusic V. (2003). Bioinformatic strategies for better understanding of immune function. In Silico Biology, Vol. 3, No. 4, (n.d.), pp. 411416

Phelan P. E., Pressley M. E., Witten P. E., Mellon M. T., Blake S. \& Kim C. H. (2005). Characterization of snakehead rhabdovirus infection in zebrafish (Danio rerio). Journal of Virology, Vol. 79, No. 10, (n.d.), pp. 1842-1852

Purcell M. K., Kurath G., Garver K. A., Herwig R. P. \& Winton J. R. (2004). Quantitative expression profiling of immune response genes in rainbow trout following infectious haematopoietic necrosis virus (IHNV) infection or DNA vaccination. Fish $\mathcal{E}$ Shellfish Immunology, Vol. 17, No. 5, (n.d.), pp. 447-462

Purcell M. K., Nichols K. M., Winton J. R., Kurath G., Thorgaard G. H., Wheeler P., Hansen J. D., Herwig R. P. \& Park L. K. (2006a). Comprehensive gene expression profiling following DNA vaccination of rainbow trout against infectious hematopoietic necrosis virus. Molecular Immunology, Vol. 43, No. 21, (n.d.), pp. 2089-2106

Purcell M. K., Nichols K. M., Winton J. R., Kurath G., Thorgaard G. H., Wheeler P., Hansen J. D., Herwig R. P. \& Park L. K. (2006b). Comprehensive gene expression profiling following DNA vaccination of rainbow trout against infectious hematopoietic necrosis virus. Molecular Immunology, Vol. 43, No. 13, (n.d.), pp. 2089-2106

Qiu Z., Dillen C., Hu J., Verbeke H., Struyf S., Van Damme J. \& Opdenakker G. (2009). Interleukin-17 regulates chemokine and gelatinase $\mathrm{B}$ expression in fibroblasts to recruit both neutrophils and monocytes. Immunobiology, Vol. 214, No. 9-10, (n.d.), pp. 835-842

Rajcani J., Mosko T. \& Rezuchova I. (2005). Current developments in viral DNA vaccines: shall they solve the unsolved? Reviews in Medical Virology, Vol. 15, No. 5, (n.d.), pp. 303-325

Robertsen B. (2008). Expression of interferon and interferon-induced genes in salmonids in response to virus infection, interferon-inducing compounds and vaccination. Fish $\mathcal{E}$ Shellfish Immunology, Vol. 25, No. 4, (n.d.), pp. 351-357

Roche S., Bressanelli S., Rey F. A. \& Gaudin Y. (2006). Crystal structure of the low-pH form of the vesicular stomatitis virus glycoprotein G. Science, Vol. 313, No. 5784, (n.d.), pp. 187-191

Roche S., Rey F. A., Gaudin Y. \& Bressanelli S. (2007). Structure of the prefusion form of the vesicular stomatitis virus glycoprotein G. Science, Vol. 315, No. 5813, (n.d.), pp. 843848

Ross T. M., Xu Y., Green T. D., Montefiori D. C. \& Robinson H. L. (2001). Enhanced avidity maturation of antibody to human immunodeficiency virus envelope: DNA vaccination with gp120-C3d fusion proteins. AIDS Research on Human Retroviruses, Vol. 17, No. 9, (n.d.), pp. 829-835

Ruiz S., Tafalla C., Cuesta A., Estepa A. \& Coll J. M. (2008). In vitro search for alternative promoters to the human immediate early-cytomegalovirus (IE-CMV) to express the G gene of viral haemorrhagic septicemia virus (VHSV) in fish epithelial cells. Vaccine, Vol. 26, No. 10, (n.d.), pp. 6620-6629

Salem M., Kenney P. B., Rexroad C. E. \& Yao J. (2008). Development of a 37 k high-density oligonucleotide microarray: a new tool for functional genome research in rainbow trout. Journal of Fish Biology, Vol. 72, No. 12, (n.d.), pp. 2187-2206 
Salonius K., Simard N., Harland R. \& Ulmer J. B. (2007). The road to licensure of a DNA vaccine. Current Opinion in Investigational Drugs, Vol. 8, No. 6, (n.d.), pp. 635-641

Samuel C. E. (2001). Antiviral Actions of Interferons. Clinical Microbiological Reviews, Vol. 14, No. 4, (n.d.), pp. 778-809

Sanders G. E., Batts W. N. \& Winton J. R. (2003). Susceptibility of zebrafish (Danio rerio) to a model pathogen, spring viremia of carp virus. Comparative Medicine, Vol. 53, No. 5, (n.d.), pp. 514-521

Secombes C. (2008). Will advances in fish immunology change vaccination strategies? Fish $\mathcal{E}$ Shellfish Immunology, Vol. 25, No. 4, (n.d.), pp. 409-416

Skeen M. J., Miller M. A. \& Ziegler H. K. (1996). Interleukin-12 as an adjuvant in the generation of protective immunity to an intracellular pathogen. Annual New York Academy Sciences, Vol. 795, No. 4, (n.d.), pp. 416-419

Slierendrecht W. J., Jensen L. B., Horlyck V. \& Koch C. (1993). Genetic-Polymorphism of Complement Component C3 in Rainbow-Trout (Oncorhynchus-Mykiss) and Resistance to Viral Hemorrhagic Septicemia. Fish \& Shellfish Immunology, Vol. 3, No. 1, (n.d.), pp. 199-206

Slierendrecht W. J., Olesen N. J., Lorenzen N., Gottschau A. \& Koch C. (1995). Alloforms of complement component $\mathrm{C} 3$ and resistance to viral haemorrhagic septicaemia in rainbow trout (Oncorhynchus mykiss). Aquaculture, Vol. 137, No. 1, (n.d.), pp. 278279

Slierendrecht W. J., Olesen N. J., Lorenzen N., Jorgensen P. E. V., Gottschau A. \& Koch C. (1996). Genetic alloforms of rainbow trout (Oncorhynchus mykiss) complement component C3 and resistance to viral haemorrhagic septicaemia under experimental conditions. Fish \& Shellfish Immunology, Vol. 6, No. 2, (n.d.), pp. 235237

Stevceva L., Moniuszko M. \& Ferrari M. G. (2006). Utilizing IL-12, IL-15 and IL-7 as mucosal vaccine adjuvants. Letters in Drug Design \& Discovery, Vol. 3, No. 4, (n.d.), pp. 586592

Sullivan C. \& Kim C. H. (2008). Zebrafish as a model for infectious disease and immune function. Fish \& Shellfish Immunology, Vol. 25, No. 2, (n.d.), pp. 341-350

Sunyer J. O., Boshra H. \& Li J. (2005). Evolution of anaphylatoxins, their diversity and novel roles in innate immunity: insights from the study of fish complement. Veterinary Immunology and Immunopathology, Vol. 108, No. 1-2, (n.d.), pp. 77-89

Ta'asan S. \& Gandlin R. (2009). BioLogic: A mathematical modeling framework for immunologists. Methods in Molecular Biology, Vol. 500, No. 3, (n.d.), pp. 429-443

Tafalla C., Chico V., Perez L., Coll J. M. \& Estepa A. (2007). In vitro and in vivo differential expression of rainbow trout (Oncorhynchus mykiss) $\mathrm{Mx}$ isoforms in response to viral haemorrhagic septicaemia virus (VHSV) G gene, poly I:C and VHSV. Fish $\mathcal{E}$ Shellfish Immunology, Vol. 23, No. 1, (n.d.), pp. 210-221

Tafalla C., Coll J. \& Secombes C. J. (2005). Expression of genes related to the early immune response in rainbow trout (Oncorhynchus mykiss) after viral haemorrhagic septicemia virus (VHSV) infection. Developmental Comparative Immunology, Vol. 29, No. 7, (n.d.), pp. 615-626

Taggart J. B., Bron J. E., Martin S. A. M., Seear P. J., Hoyheim B., Talbot R., Carmichael S. N., Villeneuve L. A. N., Sweeney G. E., Houlihan D. F., Secombes C. J., Tocher D. R. \& Teale A. J. (2008). A description of the origins, design and performance of the 
TRAITS-SGP Atlantic salmon Salmo salar L. cDNA microarray. Journal of Fish Biology, Vol. 72, No. 15, (n.d.), pp. 2071-2094

Takano T., Iwahori A., Hirono I. \& Aoki T. (2004). Development of a DNA vaccine against hirame rhabdovirus and analysis of the expression of immune-related genes after vaccination. Fish \& Shellfish Immunology, Vol. 17, No. 3, (n.d.), pp. 367-374

Taniguchi Y., Choi P. J., Li G. W., Chen H., Babu M., Hearn J., Emili A. \& Xie X. S. (2010). Quantifying E. coli proteome and transcriptome with single-molecule sensitivity in single cells. Science, Vol. 329, No. 5991, (n.d.), pp. 533-538

Theofilopoulos A. N., Baccala R., Beutler B. \& Kono D. H. (2005). Type I interferons (alpha/beta) in immunity and autoimmunity. Annual Review of Immunology, Vol. 23, No. 2, (n.d.), pp. 307-336

Thompson J. M. \& Iwasaki A. (2008). Toll-like receptors regulation of viral infection and disease. Advances in Drug Delivery Reviews, Vol. 60, No. 7, (n.d.), pp. 786-794

Tian J. Y., Sun X. Q. \& Chen X. G. (2008). Formation and oral administration of alginate microspheres loaded with pDNA coding for lymphocystis disease virus (LCDV) to Japanese flounder. Fish \& Shellfish Immunology, Vol. 24, No. 5, (n.d.), pp. 592-599

Trifari S., Kaplan C. D., Tran E. H., Crellin N. K. \& Spits H. (2009). Identification of a human helper $\mathrm{T}$ cell population that has abundant production of interleukin 22 and is distinct from $\mathrm{T}(\mathrm{H})-17, \mathrm{~T}(\mathrm{H}) 1$ and $\mathrm{T}(\mathrm{H}) 2$ cells. Nature Immunology, Vol. 10, No. 8, (n.d.), pp. 864-871

Vestergaard-Jorgensen P. E. (1972). Egtved virus: antigenic variation in 76 virus isolates examined in neutralization test and by means of the fluorescent antibody technique. Symposiums of the Zoological Society, Vol. 30, No. 3, (n.d.), pp. 333-339

Villiers M. B., Villiers C. L., Laharie A. M. \& Marche P. N. (1999a). Amplification of the antibody response by $\mathrm{C} 3 \mathrm{~b}$ complexed to antigen through an ester link. Journal Immunology, Vol. 162, No. 6, (n.d.), pp. 3647-3652

Villiers M. B., Villiers C. L., Laharie A. M. \& Marche P. N. (1999b). Different stimulating effects of complement $\mathrm{C} 3 \mathrm{~b}$ and complete Freund's adjuvant on antibody response. Immunopharmacology, Vol. 42, No. 1-3, (n.d.), pp. 151-157

von Schalburg K. R., Cooper G. A., Leong J., Robb A., Lieph R., Rise M. L., Davidson W. S. \& Koop B. F. (2008). Expansion of the genomics research on Atlantic salmon Salmo salar L. project (GRASP) microarray tools. Journal of Fish Biology, Vol. 72, No. 10, (n.d.), pp. 2051-2070

von Schalburg K. R., Rise M. L., Brown G. D., Davidson W. S. \& Koop B. F. (2005a). A comprehensive survey of the genes involved in maturation and development of the rainbow trout ovary. Biological Reproduction, Vol. 72, No. 6, (n.d.), pp. 687-699

von Schalburg K. R., Rise M. L., Cooper G. A., Brown G. D., Gibbs A. R., Nelson C. C., Davidson W. S. \& Koop B. F. (2005b). Fish and chips: various methodologies demonstrate utility of a 16,006-gene salmonid microarray. BMC Genomics, Vol. 6, No. 1, (n.d.), pp. 126-136

Winton J. R., Arakawa C. K., Lannan C. N. \& Fryer J. L. (1988). Neutralizing monoclonal antibodies recognize antigenic variants among isolates of infectious hematopoietic necrosis. Diseases Aquatic Organisms, Vol. 4, No. 1, (n.d.), pp. 199-204

Wright A. K., Briles D. E., Metzger D. W. \& Gordon S. B. (2008). Prospects for use of interleukin-12 as a mucosal adjuvant for vaccination of humans to protect against respiratory pneumococcal infection. Vaccine, Vol. 26, No. 38, (n.d.), pp. 4893-4903 
Yasuike M., Kondo H., Hirono I. \& Aoki T. (2007). Difference in Japanese flounder, Paralichthys olivaceus gene expression profile following hirame rhabdovirus (HIRRV) G and N protein DNA vaccination. Fish \& Shellfish Immunology, Vol. 23, No. 4, (n.d.), pp. 531-541

Yu J. J. \& Gaffen S. L. (2008). Interleukin-17: a novel inflammatory cytokine that bridges innate and adaptive immunity. Frontiers of Bioscience, Vol. 13, No. 1, (n.d.), pp. 170177

Zhang Z., Swain T., Bogwald J., Dalmo R. A. \& Kumari J. (2009). Bath immunostimulation of rainbow trout (Oncorhynchus mykiss) fry induces enhancement of inflammatory cytokine transcripts, while repeated bath induce no changes. Fish $\mathcal{E}$ Shellfish Immunology, Vol. 26, No. 5, (n.d.), pp. 677-684

Zheng L. Y., Mou L., Lin S., Lu R. M. \& Luo E. J. (2005). Enhancing DNA vaccine potency against hantavirus by co-administration of interleukin-12 expression vector as a genetic adjuvant. Clinical Medicine Journal (England), Vol. 118, No. 4, (n.d.), pp. 313319 


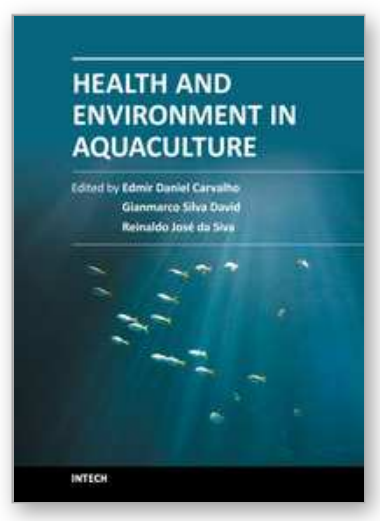

\author{
Health and Environment in Aquaculture \\ Edited by Dr. Edmir Carvalho
}

ISBN 978-953-51-0497-1

Hard cover, 414 pages

Publisher InTech

Published online 11, April, 2012

Published in print edition April, 2012

Aquaculture has been expanding in a fast rate, and further development should rely on the assimilation of scientific knowledge of diverse areas such as molecular and cellular biology, and ecology. Understanding the relation between farmed species and their pathogens and parasites, and this relation to environment is a great challenge. Scientific community is involved in building a model for aquaculture that does not harm ecosystems and provides a reliable source of healthy seafood. This book features contributions from renowned international authors, presenting high quality scientific chapters addressing key issues for effective health management of cultured aquatic animals. Available for open internet access, this book is an effort to reach the broadest diffusion of knowledge useful for both academic and productive sector.

\title{
How to reference
}

In order to correctly reference this scholarly work, feel free to copy and paste the following:

P. Encinas, E. Gomez-Casado, A. Estepa and J.M. Coll (2012). Use of Microarray Technology to Improve DNA Vaccines in Fish Aquaculture - The Rhabdoviral Model, Health and Environment in Aquaculture, Dr. Edmir Carvalho (Ed.), ISBN: 978-953-51-0497-1, InTech, Available from: http://www.intechopen.com/books/healthand-environment-in-aquaculture/use-of-microarray-technology-to-improve-vaccines-in-aquaculture-therhabdoviral-model-

\section{INTECH}

open science | open minds

\author{
InTech Europe \\ University Campus STeP Ri \\ Slavka Krautzeka 83/A \\ 51000 Rijeka, Croatia \\ Phone: +385 (51) 770447 \\ Fax: +385 (51) 686166 \\ www.intechopen.com
}

\author{
InTech China \\ Unit 405, Office Block, Hotel Equatorial Shanghai \\ No.65, Yan An Road (West), Shanghai, 200040, China \\ 中国上海市延安西路65号上海国际贵都大饭店办公楼 405 单元 \\ Phone: +86-21-62489820 \\ Fax: +86-21-62489821
}


(C) 2012 The Author(s). Licensee IntechOpen. This is an open access article distributed under the terms of the Creative Commons Attribution 3.0 License, which permits unrestricted use, distribution, and reproduction in any medium, provided the original work is properly cited. 